\title{
Author Index to Volume 13 (1994)
}

Berne, R.W., Managing Diversity: A Comment, (1) $71-74$

Boettke, P.J., The Political Infrastructure of Economic Development, (2) 89-100

Cavaleri, S.A., "Soft" Systems Thinking: A PreCondition for Organizational Learning, (4) 259267

Choi, Y.B., Industrial Policy for Economic Development: Lessons from South Korean Experience, (2) 111-121

Coman, A. and Ronen, B., IS Management by Constraints: Coupling IS Effort to Changes in Business Bottlenecks (1) 65-70

De Waele, M., Guest-Editor's Preface: Self-Management: Road to a Productive, Healthy and Self-Sustaining Organizational Milieu?, (3) 153-164

Djimopoulos, E.S. and Kim, Y.-S., Guest-Editors' Preface: The Role of Government in Competitive Economies, (2) 85-88

Djimopoulos, E.S., Managing Trade Policy for Development, (2) 101-110

Dowlatshahi, S., Reengineering in Higher Education: A Case Study (Short Communication), (4) 303-307

Gong, B.-H., Government Policy for Firm-Specific Efficiency, (2) 123-128

Ifeka, C., Self-Management and Development, (3) 233-240

Ishida, H., Amoeba Management at Kyocera Corporation, (3) 183-195

Kim, Y.-S., see Djimopoulos, E.S., (2) 85-88

Kim, Y.-S., Japan's Technology Policy and the United States, (2) 129-137

Lam, W.F., see Ostrom, E., (3) 197-207

Lee, M., see Ostrom, E., (3) 197-207

Lin, B. and Schneider, H., Artificial Intelligence Systems in Manufacturing: An Overview and Research Perspective, (4) 283-293

Mackenzie, K.D., The Science of an Organization. Part I: A New Model of Organizational Learning, (4) 249-258

McLean, G.N., see Persico Jr., J., (1) 11-18

Nilakant, V., Transdisciplinary Approach to a Theory of Performance in Organizations, (1) $41-48$

IOS Press

Human Systems Management 13 (1994) 315
Oh, K.-S., Financial Liberalization and Asset Market Behavior, (2) 139-152

Ostrom, E., Lam, W.F. and Lee, M., The Performance of Self-Governing Irrigation Systems in Nepal, (3) 197-207

Persico, Jr., J. and McLean, G.N., The Evolving Merger of Socio-Technical Systems and Quality Improvement Theories, (1) 11-18

Poole, M. and Whitfield, K., Theories and Evidence on the Growth and Distribution of Profit Sharing and Employees Shareholding Schemes, (3) 209-220

Richter, F.-J., The Emergence of Corporate Alliance Networks - Convertion to Self-Organization, (1) 19-26

Romme, A.G.L., The Process of Self-Renewal by Management Teams, (1) 49-55

Ronen, B., see Coman, A., (1) 65-70

Schneider, H., see Lin, B., (4) 283-293

Selvarajah, C.T., Training System Effectiveness in Australia, (4) 295-302

Shenhar, A.J. and Thamhain, H.J., A New Mixture of Management Skills: Meeting the High-Technology Managerial Challenges, (1) 27-40

Suomi, R., Co-operation in the Field of Information Systems, (1) 57-64

Tang, S.-Y., Building Community Organizations: Credible Commitment and the New Institutional Economics, (3) 221-232

Thamhain, H.J., see Shenhar, A.J., (1) 27-40

Uphoff, N., Catalyzing Self-Management Capabilities: A Post-Newtonian Perspective, (3) 171181

Whitfield, K., see Poole, M., (3) 209-220

Zeffane, R., The Influence of Computer Usage on Employees and Managers' Satisfaction: Findings from the Australian Telecommunications, (4) 269-282

Zeleny, M., Editorial: Foreign Policy: A Human Systems View, (1) 1-4

Zeleny, M., W. Edwards Deming (1900-1993) (Obituary), (1) 75-78

Zeleny, M., Editorial: Towards Trade-Offs-Free Management, (4) 241-243

Zeleny, M., N. Georgescu-Roegen (1906-1994) (Obituary), (4) 315-316 